\title{
Lusioersily
}

\section{Phosphoenolpyruvate phosphomutase activity in an L-phosphonoalanine-mineralizing strain of Burkholderia cepacia}

Ternan, N., McGrath, JW., \& Quinn, JP. (1998). Phosphoenolpyruvate phosphomutase activity in an Lphosphonoalanine-mineralizing strain of Burkholderia cepacia. Applied and Environmental Microbiology, 64(6), 2291-2294. http://aem.asm.org/cgi/content/full/64/6/2291

Link to publication record in Ulster University Research Portal

Published in:

Applied and Environmental Microbiology

Publication Status:

Published (in print/issue): 01/06/1998

\section{Document Version}

Publisher's PDF, also known as Version of record

\section{General rights}

Copyright for the publications made accessible via Ulster University's Research Portal is retained by the author(s) and / or other copyright owners and it is a condition of accessing these publications that users recognise and abide by the legal requirements associated with these rights.

\section{Take down policy}

The Research Portal is Ulster University's institutional repository that provides access to Ulster's research outputs. Every effort has been made to ensure that content in the Research Portal does not infringe any person's rights, or applicable UK laws. If you discover content in the Research Portal that you believe breaches copyright or violates any law, please contact pure-support@ulster.ac.uk. 


\title{
Phosphoenolpyruvate Phosphomutase Activity in an L-Phosphonoalanine-Mineralizing Strain of Burkholderia cepacia
}

\author{
NIGEL G. TERNAN, ${ }^{1 *}$ JOHN W. MCGRATH, ${ }^{1,2}$ AND JOHN P. QUINN ${ }^{1,2}$ \\ School of Biology and Biochemistry ${ }^{1}$ and the QUESTOR Centre, ${ }^{2}$ \\ The Queen's University of Belfast, Belfast, Northern Ireland
}

Received 22 December 1997/Accepted 10 April 1998

\begin{abstract}
A strain of Burkholderia cepacia isolated by enrichment culture utilized L-2-amino-3-phosphonopropionic acid (phosphonoalanine) at concentrations up to $20 \mathrm{mM}$ as a carbon, nitrogen, and phosphorus source in a phosphate-insensitive manner. Cells contained phosphoenolpyruvate phosphomutase activity, presumed to be responsible for cleavage of the $\mathrm{C}-\mathrm{P}$ bond of phosphonopyruvate, the transamination product of $\mathrm{L}$-phosphonoalanine; this was inducible in the presence of phosphonoalanine.
\end{abstract}

Organophosphonates are characterized by the presence of a stable, covalent carbon-to-phosphorus $(\mathrm{C}-\mathrm{P})$ bond. In the majority of previous studies they have been utilized only under phosphate-limited conditions and only as sole sources of phosphorus for microbial growth $(3,4,21,22)$. The $\mathrm{C}-\mathrm{P}$ bond may be cleaved by at least three distinct bacterial enzymes: the C-P lyase enzyme complex(es) $(17,24,25,27,28)$, phosphonoacetaldehyde hydrolase $(5,6,9,12)$, and phosphonoacetate hydrolase (14-16). The latter enzyme is unique in that its expression is independent of the phosphate status of the cell and is inducible solely by phosphonoacetate. It is likely that organophosphonate biodegradation in the environment is mediated largely by a $\mathrm{C}-\mathrm{P}$ lyase(s), with organisms capable of mineralizing organophosphonates as sources of carbon and energy being rare $(2,13)$.

Phosphonoalanine (2-amino-3-phosphonopropionic acid) is one of the naturally occurring $\mathrm{C}-\mathrm{P}$ compounds synthesized by lower organisms, such as the sea anemone Zoanthus sociatus (10) and the protozoan Tetrahymena pyriformis $(8,23,29)$. In this paper, we report the isolation of a bacterium capable of mineralizing L-phosphonoalanine as a carbon, energy, nitrogen, and phosphorus source independently of the phosphate status of the cell.

Enrichment was carried out with a basal mineral salts medium which contained the following (per liter): $\mathrm{KCl}, 0.2 \mathrm{~g}$; $\mathrm{MgSO}_{4} \cdot 7 \mathrm{H}_{2} \mathrm{O}, 0.2 \mathrm{~g} ; \mathrm{CaCl}_{2} \cdot 2 \mathrm{H}_{2} \mathrm{O}, 0.01 \mathrm{~g}$; ferric ammonium citrate, $1.0 \mathrm{mg}$; trace element solution (11), $1 \mathrm{ml}$; and vitamin solution (14), $1 \mathrm{ml}$. Filter-sterilized $(0.22-\mu \mathrm{m}$ pore size) DLphosphonoalanine $(8 \mathrm{mM})$ was routinely added as a carbon, energy, nitrogen, and phosphorus source. The $\mathrm{pH}$ of the medium was initially adjusted to 7.2, and where required, filtersterilized solutions of sodium pyruvate as a carbon source (final concentration, $10 \mathrm{~g}$ liter $^{-1}$ ), $\mathrm{NH}_{4} \mathrm{Cl}$ as an inorganic nitrogen source (final concentration, $5 \mathrm{~g} \mathrm{liter}^{-1}$ ), and/or phosphate buffer (final concentration, $1 \mathrm{mM}$ ) were added to the medium. Enrichment cultures $(25 \mathrm{ml}$ in 250-ml Erlenmeyer flasks) were inoculated with a $0.5 \%$ ( $\mathrm{vol} / \mathrm{vol})$ composite inoculum from an activated sludge plant (Dunmurry, Northern

\footnotetext{
* Corresponding author. Present address: Biotechnology Research Unit, School of Applied Biological and Chemical Sciences, University of Ulster, Cromore Road, Coleraine, Co. Londonderry, Northern Ireland BT52 1SA. Phone: 44 (0) 1265 323063. Fax: 44 (0) 1265324906. E-mail:ng.ternan@ulst.ac.uk.
}

Ireland), a laundry waste disposal lagoon (Summit Lake, Wis.), and a sheep dip disposal site (County Antrim, Northern Ireland). All sites were known to have a history of exposure to organophosphonates. Cultures were incubated at $28^{\circ} \mathrm{C}$ on an orbital shaker at $100 \mathrm{rpm}$. Microbial growth was measured by the increase in optical density at $650 \mathrm{~nm}\left(\mathrm{OD}_{650}\right)$ using a PyeUnicam 8265 UV-visible light spectrophotometer (Pye-Unicam Ltd., Cambridge, United Kingdom). Release of inorganic phosphate and ammonium into culture supernatants was monitored by the methods of Fiske and SubbaRow (7) and Weatherburn (30), respectively.

Three gram-negative isolates, each capable of growth on 8 mM DL-phosphonoalanine as a carbon, nitrogen, and phosphorus source were obtained following five rounds of serial enrichment. Of these, isolate Pal6 grew most quickly on phosphonoalanine and was chosen for further investigation. It was identified by the National Collection of Industrial and Marine Bacteria Ltd., Aberdeen, Scotland, as a strain of Burkholderia cepacia.

When DL-phosphonoalanine $(8 \mathrm{mM})$ was supplied as a carbon, nitrogen, and phosphorus source for growth of $B$. cepacia Pal6, some $47 \%$ of substrate phosphorus and $44 \%$ of substrate nitrogen was released concomitantly with growth as $\mathrm{P}_{i}$ and ammonium (results not shown). When the compound was supplied as the sole phosphorus source (Fig. 1), transient release of approximately $30 \%$ of substrate phosphorus to the medium as $\mathrm{P}_{\mathrm{i}}$ was observed; this phenomenon has not previously been reported for the utilization of any organophosphorus compound as a phosphorus source. When B. cepacia Pal6 was grown on DL-phosphonoalanine as a nitrogen and phosphorus (Fig. 2) or nitrogen source, removal of $50 \%$ of phosphonoalanine from the medium was demonstrated by the method of Moore and Stein (18), along with release of just less than 50\% of substrate phosphorus as $\mathrm{P}_{\mathrm{i}}$. A subsequent experiment in which the D- and L-enantiomers were separately supplied as sole sources of phosphorus indicated that only L-phosphonoalanine supported growth of B. cepacia Pal6. It is therefore clear that the catabolism of L-phosphonoalanine by this isolate is independent of the phosphate status of the cell, a marked departure from the many examples of classical pho reguloncontrolled biodegradation of organophosphonates reported in the literature $(26,27)$.

B. cepacia Pal6 was grown on a range of DL-phosphonoalanine concentrations as carbon and nitrogen source in the pres- 


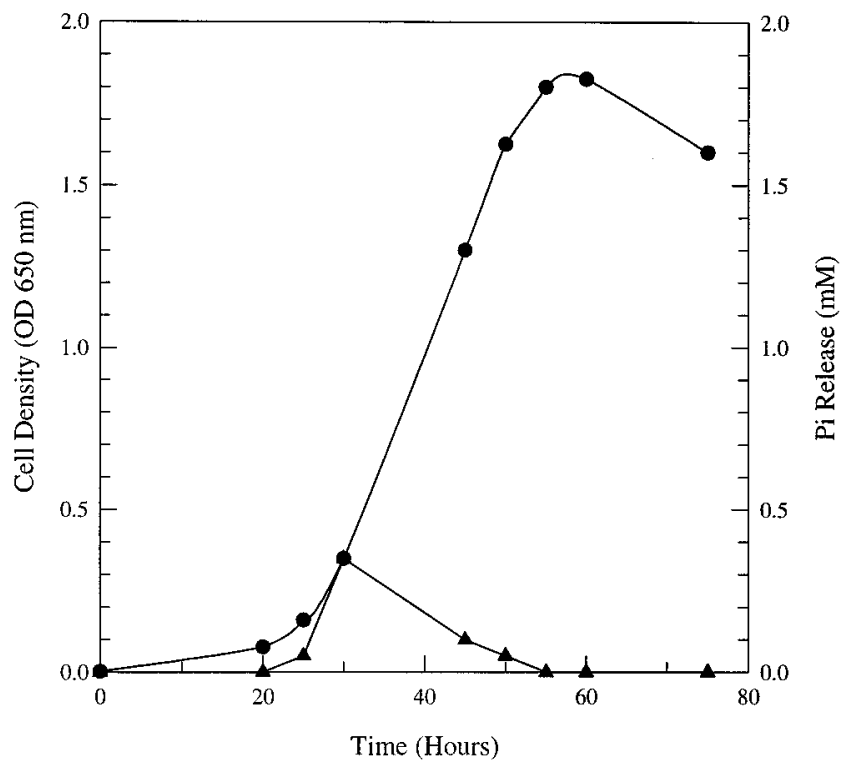

FIG. 1. Growth of B. cepacia Pal6 on phosphonoalanine $(1 \mathrm{mM})$ as the sole phosphorus source, with $\mathrm{NH}_{4} \mathrm{Cl}$ as a nitrogen source $\left(5 \mathrm{~g} \mathrm{liter}^{-1}\right)$ and pyruvate as a carbon source $\left(10 \mathrm{~g} \mathrm{liter}^{-1}\right)$. Symbols: $\bullet, \mathrm{OD}_{650} ; \boldsymbol{\Lambda}$, phosphate release.

ence of $1 \mathrm{mM}$ inorganic phosphate. The cell yield was proportional to the concentration of phosphonoalanine supplied up to $20 \mathrm{mM}$, the highest concentration tested, again with release of less than $50 \%$ substrate phosphorus and nitrogen to the medium (results not shown), indicating no toxicity on the part of either the substrate or its breakdown products at these concentrations.

In addition to phosphonoalanine, B. cepacia Pal6 was able to utilize 6 of 14 organophosphonate substrates supplied as the sole phosphorus source (Table 1); however, with the exception of 2-aminoethylphosphonic acid (2AEP), no phosphate release

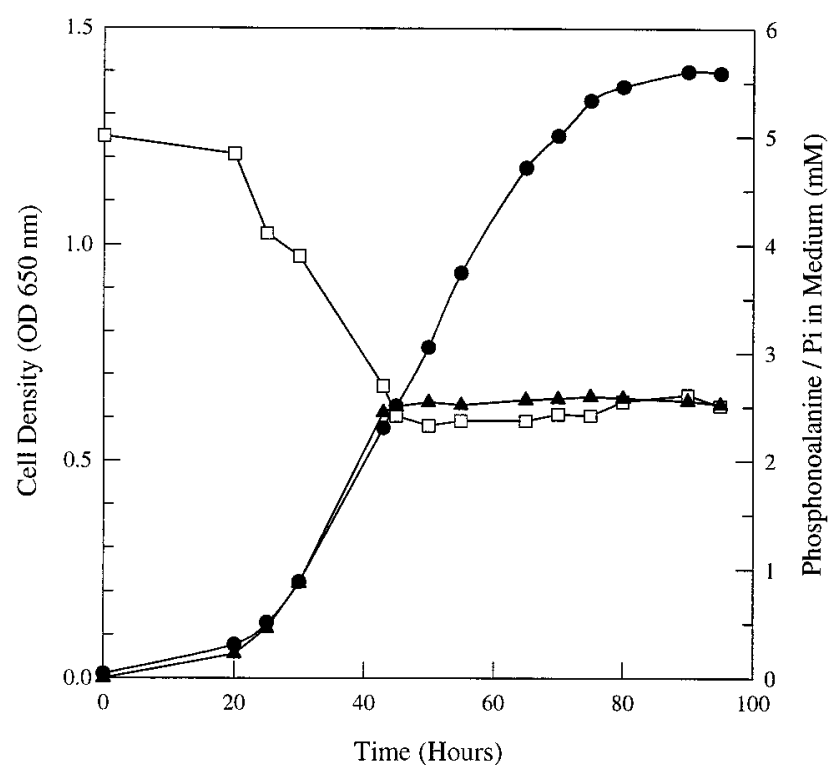

FIG. 2. Growth of B. cepacia Pal6 on phosphonoalanine $(5 \mathrm{mM})$ as a nitrogen and phosphorus source, with pyruvate as a carbon source $\left(10 \mathrm{~g} \mathrm{liter}^{-1}\right)$ Symbols: $\bullet, \mathrm{OD}_{650} ; \boldsymbol{\Delta}$, phosphate release $(\mathrm{mM}) ; \square$, phosphonoalanine remaining in medium $(\mathrm{mM})$.
TABLE 1. Range of organophosphonate substrates utilized by B. cepacia Pal6 as the sole phosphorus source

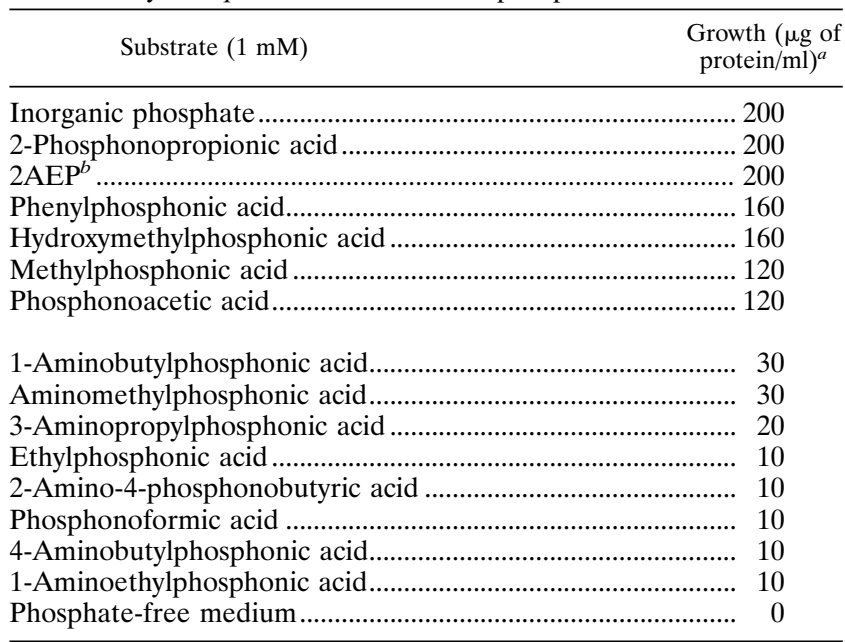

${ }^{a}$ Results were scored negative if the protein yield, as measured by the method of Binks et al. (1), was less than $20 \%$ of that of the positive control containing 1 $\mathrm{mM}$ inorganic phosphate. Results are means of duplicates which on no occasion varied by more than $5 \%$.

b $2 \mathrm{AEP}$ was also metabolized as the sole carbon, nitrogen, and phosphorus source.

was observed during growth on these compounds, suggesting classical pho regulon control of their biodegradation and the involvement of a $\mathrm{C}-\mathrm{P}$ lyase(s) or similar enzymes. B. cepacia Pal6 was also capable of growing on 2AEP as a carbon, energy, nitrogen, and phosphorus source, with concomitant release of excess phosphorus and nitrogen to the medium as inorganic phosphate and ammonium, respectively. It did not utilize any of the other phosphonates tested as the carbon and/or nitrogen and phosphorus source. The metabolism by B. cepacia Pal6 of 2AEP as a carbon, nitrogen and phosphorus source suggests that a phosphate-deregulated pathway is also responsible for the mineralization of this compound.

No in vitro cleavage of the $\mathrm{C}-\mathrm{P}$ bond of phosphonoalanine was detected in cell extracts of B. cepacia Pal6 grown on the compound, nor did such extracts contain detectable phosphonatase or phosphonoacetate hydrolase activities when assayed by the methods of La Nauze et al. (12) and McMullan and Quinn (16), respectively. The only other documented enzyme capable of in vitro-detectable $\mathrm{C}-\mathrm{P}$ bond cleavage is phosphoenolpyruvate phosphomutase, which catalyses the reversible intramolecular rearrangement of phosphonopyruvate to phosphoenolpyruvate (PEP); it has been implicated in the utilization of phosphonoalanine as the sole phosphorus source by Pseudomonas gladioli B-1 $(19,20)$. The initial step in this catabolic pathway is the transamination of phosphonoalanine to phosphonopyruvate (20); no such activity was detected in cells of B. cepacia Pal6 grown on phosphonoalanine. However, extracts prepared from D,L-phosphonoalanine-grown cells did indeed contain PEP phosphomutase activity when assayed by the method of Nakashita et al. (19); this was inducible above a basal level (some 17\% of the maximum) in the presence of DL-phosphonoalanine. The induction of PEP phosphomutase activity in resting cells of $B$. cepacia Pal6 pregrown on complete mineral salts medium and resuspended $(1 \mathrm{~g}$ of cells $/ 50 \mathrm{ml})$ with DL-phosphonoalanine as a sole carbon, nitrogen, and phosphorus source is shown in Fig. 3.

PEP phosphomutase activity in cell extracts was obtained only when phosphonopyruvate was supplied as a substrate, 


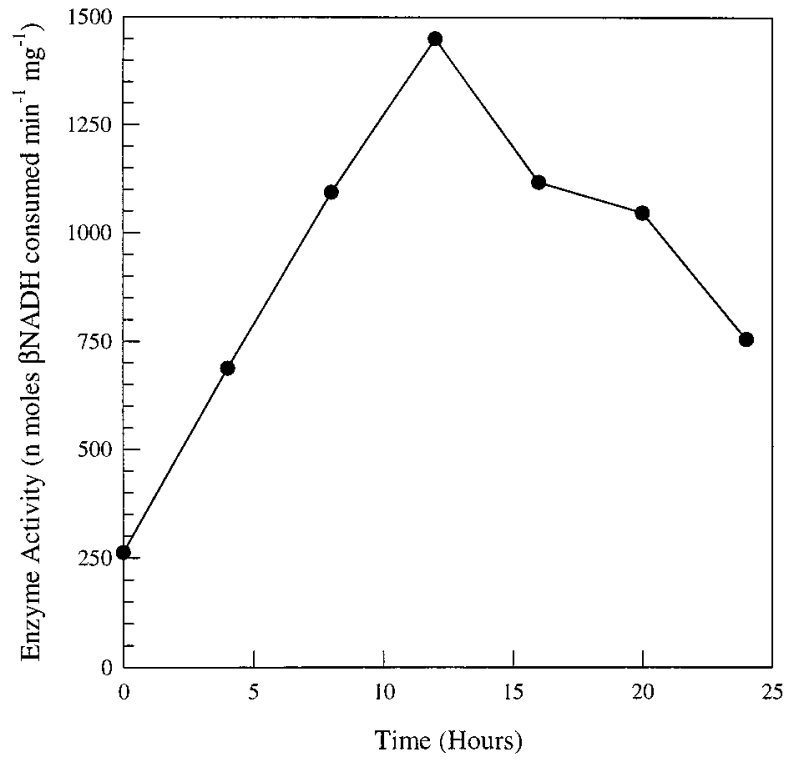

FIG. 3. Induction of PEP phosphomutase activity in resting cells of B. cepacia $\mathrm{Pal} 6$ pregrown on complete medium and resuspended in mineral salts containing $8 \mathrm{mM}$ phosphonoalanine as a carbon, nitrogen, and phosphorus source. Symbol: $\bullet$, PEP phosphomutase activity.

with no activity being observed in the presence of phosphonoalanine, 2AEP, phosphonoacetaldehyde, or phosphonoacetate. No activity was obtained in the control assays lacking either cell extract or phosphonopyruvate. That this activity is responsible for cleavage of the $\mathrm{C}-\mathrm{P}$ bond of phosphonoalanine cannot be definitely confirmed, however, in the absence of a mutant strain of B. cepacia Pal6 deficient in PEP phosphomutase activity. It is unlikely, given the previously demonstrated involvement of PEP phosphomutase in the utilization of phosphonoalanine by $P$. gladioli $\mathrm{B}-1$ as the sole phosphorus source $(19,20)$, that the enzyme is merely gratuitously induced by phosphonoalanine in B. cepacia Pal6. Moreover, the hypothesis that PEP phosphomutase is responsible for the cleavage of the $\mathrm{C}-\mathrm{P}$ bond of phosphonoalanine via a phosphonopyruvate intermediate is also strengthened by the fact that activity of none of the existing known $\mathrm{C}-\mathrm{P}$ bond-cleaving enzymes was obtained in cell extracts of B. cepacia Pal6.

As cells of $B$. cepacia Pal6 grown on mineral salts supplemented with carbon, nitrogen, and phosphorus sources in the absence of phosphonoalanine were observed to have relatively high levels of constitutive PEP phosphomutase activity (Fig. 3), it was considered likely that the organism, like $P$. gladioli $\mathrm{B}-1$, would also be capable of producing a $\mathrm{C}-\mathrm{P}$ bond-containing compound. A sample of broth was taken prior to inoculation and again following 24-h growth of B. cepacia Pal6 on complete medium containing $5 \mathrm{mM}$ inorganic phosphate as the sole source of phosphorus. ${ }^{31} \mathrm{P}$-labeled nuclear magnetic resonance spectra were obtained for both samples (19), and a new signal, with a shift relative to inorganic phosphate of $13.20 \mathrm{ppm}$, was observed in the 24-h sample. The experiment was repeated, with identical results. The shift obtained for the unknown compound was similar, but did not correspond, to those shifts obtained for 2-phosphonoacetaldehyde (5.55 ppm), phosphonopyruvate $(6.40 \mathrm{ppm}), 2$-aminoethylphosphonate (15.90 ppm), or phosphonoalanine $(14.03 \mathrm{ppm})$. The appearance of this additional resonance thus suggests the production of a $\mathrm{C}-\mathrm{P}$ bond-containing compound and is further confirmation of the presence of PEP phosphomutase activity in B. cepacia Pal6.
The phosphonoalanine biodegradation pathway in B. cepacia Pal6 would appear to be different from that described for both rats and Tetrahymena (8). In cell-free preparations from these organisms, phosphonoalanine biodegradation was shown to involve a deamination to phosphonopyruvate, which is converted by decarboxylation to 2-phosphonoacetaldehyde, followed by either dephosphonylation or amination of the aldehyde to give acetaldehyde or $2 \mathrm{AEP}$, respectively (8). In B. cepacia Pal6, PEP produced by the intramolecular rearrangement of phosphonopyruvate by PEP phosphomutase would readily enter intermediary metabolism, serving as a carbon and phosphorus source with excess phosphorus being excreted as $\mathrm{P}_{\mathrm{i}}$.

The isolation of three different phosphonoalanine-degrading microorganisms by enrichment culture suggests that this ability may be relatively common in the natural environment. Phosphonoalanine is a biogenic organophosphonate; it is therefore unsurprising that microbial systems for its effective utilization exist. In addition to being capable of producing a $\mathrm{C}-\mathrm{P}$ bondcontaining compound, B. cepacia Pal6 is the first microorganism reported to mineralize the L-enantiomer of phosphonoalanine and joins a growing number of reports of microorganisms capable of deregulated scission of the $\mathrm{C}-\mathrm{P}$ bond of organophosphonates.

This work was supported by a postgraduate studentship to Nigel G. Ternan from the Queen's University of Belfast and a Distinction Award from the Department of Education for Northern Ireland to John W. McGrath.

We thank H. B. F. Dixon, Department of Biochemistry, University of Cambridge, Cambridge, United Kingdom, for the generous gift of 3-phosphonopyruvate.

\section{REFERENCES}

1. Binks, P. R., C. E. French, S. Nicklin, and N. E. Bruce. 1996. Degradation of pentaerythritol tetranitrate by Enterobacter cloacae PB2. Appl. Environ. Microbiol. 62:1214-1219.

2. Cook, A. M., C. G. Daughton, and M. Alexander. 1978. Phosphonate utilization by bacteria. J. Bacteriol. 133:85-90.

3. Daughton, C. G., A. M. Cook, and M. Alexander. 1979. Bacterial conversion of alkylphosphonates to natural products via carbon-phosphorus bond cleavage. J. Agric. Food Chem. 27:1375-1382.

4. Daughton, C. G., A. M. Cook, and M. Alexander. 1979. Biodegradation of phosphonate toxicants yields methane or ethane on cleavage of the C-P bond. FEMS Microbiol. Lett. 5:91-93.

5. Dumora, C., A.-M. Lacoste, and A. Cassaigne. 1983. Purification and properties of 2-aminoethylphosphonate:pyruvate aminotransferase from Pseudomonas aeruginosa. Eur. J. Biochem. 133:119-125.

6. Dumora, C., A.-M. Lacoste, and A. Cassaigne. 1989. Phosphonoacetaldehyde hydrolase from Pseudomonas aeruginosa: purification properties and comparison with Bacillus cereus enzyme. Biochim. Biophys. Acta 997:193198.

7. Fiske, C. H., and Y. SubbaRow. 1925. The colourimetric determination of phosphorus. J. Biol. Chem. 66:375-400.

8. Horigane, A., M. Horiguchi, and T. Matsumoto. 1980. Metabolism of 2-amino-3-phosphono[3- $\left.{ }^{14} \mathrm{C}\right]$ propionic acid in cell free preparations of Tetrahymena. Biochim. Biophys. Acta 618:383-388.

9. Jiang, W., W. W. Metcalf, K.-S. Lee, and B. L. Wanner. 1995. Molecular cloning of the genes for phosphonate breakdown by the phosphonatase pathway of Salmonella typhimurium LT2. J. Bacteriol. 177:6411-6421.

10. Kitteredge, J. S., and R. R. Hughes. 1964. The occurrence of $\alpha$-amino- $\beta$ propionic acid in the zoanthid, Zoanthus sociatus, and the ciliate, Tetrahymena pyriformis. Biochemistry 3:991-996.

11. Kreig, N. R. 1981. Enrichment and isolation, p. 112-142. In P. Gerhardt, R. G. E. Murray, R. N. Costilow, E. W. Nester, W. A. Wood, N. R. Kreig, and G. B. Phillips (ed.), Manual of methods for general bacteriology. American Society for Microbiology, Washington, D.C.

12. La Nauze, J. M., H. Rosenberg, and D. C. Shaw. 1970. The enzymatic cleavage of the carbon-phosphorus bond: purification and properties of phosphonatase. Biochim. Biophys. Acta 212:332-350.

13. McGrath, J. W., N. G. Ternan, and J. P. Quinn. 1997. Utilization of organophosphonates by environmental microorganisms. Lett. Appl. Microbiol. 24: 69-73.

14. McGrath, J. W., G. B. Wisdom, G. McMullan, M. J. Larkin, and J. P. Quinn. 1995. The purification and properties of phosphonoacetate hydrolase, a 
novel carbon-phosphorus bond-cleavage enzyme from Pseudomonas fluorescens 23F. Eur. J. Biochem. 234:225-230.

15. McMullan, G., and J. P. Quinn. 1992. Detection of a novel carbon phosphorus bond cleavage activity in cell free extracts of an environmental Pseudomonas fluorescens isolate. Biochem. Biophys. Res. Commun. 184: 1022-1027.

16. McMullan, G., and J. P. Quinn. 1994. In vitro characterization of a phosphate starvation-independent carbon-phosphorus bond cleavage activity in Pseudomonas fluorescens 23F. J. Bacteriol. 176:320-324.

17. Metcalf, W. W., and B. L. Wanner. 1993. Evidence for a fourteen-gene phnC-phnP locus for phosphonate metabolism in Escherichia coli. Gene 129: 27-32.

18. Moore, S., and W. H. Stein. 1954. A modified ninhydrin method for the determination of amino acids and related compounds. J. Biol. Chem. 211: 907-913.

19. Nakashita, H., A. Shimazu, and H. Seto. 1991. A new screening method for $\mathrm{C}-\mathrm{P}$ compound producing organisms by the use of phosphoenolpyruvate phosphomutase. Agric. Biol. Chem. 55:2825-2829.

20. Nakashita, H., A. Shimazu, T. Hidaka, and H. Seto. 1992. Purification an characterization of phosphoenolpyruvate phosphomutase from Pseudomonas gladioli B-1. J. Bacteriol. 174:6857-6861.

21. Quinn, J. P., J. M. M. Peden, and R. E. Dick. 1989. Carbon-phosphorus bon cleavage by gram positive soil bacteria. Appl. Microbiol. Biotechnol. 31: 283-287.
22. Schowanek, D., and W. Verstraete. 1990. Phosphonate utilization by bacterial cultures and enrichments from environmental samples. Appl. Environ. Microbiol. 56:2501-2510.

23. Smith, J. D., and J. H. Law. 1970. Phosphonic acid metabolism in Tetrahymena. Biochemistry 9:2152-2157.

24. Wackett, L. P., S. L. Shames, C. P. Venditti, and C. T. Walsh. 1987. Bacterial carbon-phosphorus lyase: products, rates, and regulation of phosphonic and phosphinic acid metabolism. J. Bacteriol. 169:710-717.

25. Wackett, L. P., B. L. Wanner, C. P. Venditti, and C. T. Walsh. 1987. Involvement of the phosphate regulon and the psiD locus in carbon-phosphorus lyase activity of Escherichia coli K-12. J. Bacteriol. 169:1753-1756.

26. Wanner, B. L. 1990. Phosphorus assimilation and its control of gene expression in E. coli, p. 152-163. In G. Hauska and R. Thauer (ed.), The molecular basis of bacterial metabolism. Springer-Verlag, Berlin, Germany.

27. Wanner, B. L. 1994. Molecular genetics of carbon-phosphorus bond cleavage in bacteria. Biodegradation 5:175-184.

28. Wanner, B. L., and W. W. Metcalf. 1992. Molecular genetic studies of a 10.9-kb operon in E. coli for phosphonate uptake and biodegradation. FEBS Microbiol. Lett. 100:133-140.

29. Warren, W. A. 1968. Biosynthesis of phosphonic acids in Tetrahymena. Biochim. Biophys. Acta 156:340-346.

30. Weatherburn, J. 1969. Phenol-hypochlorite reaction for determination of ammonia. Anal. Chem. 39:971-974. 